NBER WORKING PAPER SERIES

\title{
THE ECONOMICS OF PREFUNDING \\ SOCIAL SECURITY AND \\ MEDICARE BENEFITS
}

\author{
Martin Feldstein \\ Andrew Samwick
}

Working Paper 6055

\author{
NATIONAL BUREAU OF ECONOMIC RESEARCH \\ 1050 Massachusetts Avenue \\ Cambridge, MA 02138 \\ June 1997
}

Martin Feldstein is professor of economics at Harvard University and president of the National Bureau of Economic Research. Andrew Samwick is assistant professor of economics at Dartmouth College and a faculty research fellow of the National Bureau of Economic Research. The current paper, which was presented on April 4th at the NBER's 1997 Macro Annual conference, extends and supersedes the results presented in Feldstein and Samwick (1996). We are grateful for comments from participants in the Harvard-MIT Public Economics Seminar, the 1996 NBER conference on Privatizing Social Security, and the participants in the NBER Macro Annual conference, particularly our discussants, and to the NBER for support of this research. This paper is part of NBER's research programs in Aging, Economic Fluctuations and Growth, Health Care and Public Economics. Any opinions expressed are those of the authors and not those of the National Bureau of Economic Research.

(C) 1997 by Martin Feldstein and Andrew Samwick. All rights reserved. Short sections of text, not to exceed two paragraphs, may be quoted without explicit permission provided that full credit, including $(\mathcal{C}$ notice, is given to the source. 
The Economics of Prefunding Social Security

and Medicare Benefits

Martin Feldstein and Andrew Samwick

NBER Working Paper No. 6055

June 1997

JEL Nos. H55, E2

Aging, Economic Fluctuations and Growth,

Health Care and Public Economics

\begin{abstract}
This paper presents a detailed analysis of the economics of prefunding benefits for the aged, focusing on Social Security but indicating some of the analogous magnitudes for prefunding Medicare benefits. We use detailed Census and Social Security information to model the transition to a fully funded system based on mandatory contributions to individual accounts. The funded system that we examine would permanently maintain the level of benefits now specified in current law and would require no new government borrowing (other than eventually selling the bonds that are officially in the Social Security trust fund). During the transition, the combined rate of payroll tax and mandatory saving rises initially by 2 percentage points (to a total of 14.4 percent) and then declines so that, in less than 20 years, it is less than the current 12.4 percent payroll tax.

We estimate the impact of such prefunding on the growth of the capital stock and the level of national income and show that the combination of higher pretax wages and lower payroll taxes could raise wages net of income and payroll taxes by more than 35 percent in the long run. We also discuss distributional issues and the way that the poor can be at least as well off as under Social Security. A stochastic simulation shows that a small increase in the mandatory saving rate would reduce the risk of receiving less than the scheduled level to less than one percent. Separate calculations are presented of the value of the "forward-looking recognition bonds" and "backwardlooking recognition bonds" which the government might issue if it decides not to pay future social security benefits explicitly.
\end{abstract}

Martin Feldstein

National Bureau of Economic Research

1050 Massachusetts Avenue

Cambridge, MA 02138

msfeldst@nber.org
Andrew Samwick

Department of Economics

Dartmouth College

6106 Rockefeller Hall

Hanover, NH 03755-3574 and NBER

samwick@dartmouth.edu 


\title{
The Economics of Prefunding Social Security and Medicare Benefits
}

\author{
Martin Feldstein and Andrew Samwick*
}

The most profound demographic trend shaping our budgetary and economic future is that older Americans are living much longer. Although the maturing of the baby boom generation will soon accelerate the aging of the population, the shift to an older age structure is a permanent change that reflects better medical care and improved life styles.

The percentage of the population 65 years old or older is projected to rise from 12 percent now to 20 percent in 2030, a 65 percent increase in the relative number of individuals eligible for Social Security retirement benefits and federally financed health care. Even more startling is the projected increase in the "very old" who are the most intensive consumers of medical care. The Census Bureau anticipates ${ }^{1}$ that the group over 75 will rise from 6.1 percent of the population in 2000 to 11.2 percent by 2050 . And the group over 85 is expected to rise from 1.6 percent of the population to 4.6 percent.

Under current law, the aging of the American population during the next four decades will

\footnotetext{
${ }^{1}$ These are the Census Bureau's intermediate projections. More rapid medical progress and greater changes in lifestyles could significantly accelerate the proportion of older persons in the population.

* Martin Feldstein is professor of economics at Harvard University and president of the National Bureau of Economic Research. Andrew Samwick is assistant professor of economics at Dartmouth College and a faculty research fellow of the National Bureau of Economic Research. The current paper, which was presented on April $4^{\text {th }}$ at the NBER's 1997 Macro Annual conference, extends and supercedes the results presented in Feldstein and Samwick (1996). We are grateful for comments from participants in the Harvard-MIT Public Economics Seminar, the 1996 NBER conference on Privatizing Social Security, and the participants in the NBER Macro Annual conference, particularly our discussants.
} 
require doubling the share of national income that the government spends on retirement income and health care for those who are no longer employed. Since medical costs rise sharply with age, the demographic trends will cause the costs of Medicare and Medicaid to rise even more rapidly than the cost of Social Security pensions.

The Social Security and Medicare programs now cost 8 percent of GDP. The federal government also spends an additional 0.4 percent of GDP on means-tested Medicaid benefits for the aged. The Congressional Budget Office projects that the total cost of these programs will rise to 16 percent of GDP in 2030 and to about 18 percent of GDP in $2050 .^{2}$

Financing such an increase in government spending on a pay-as-you-go basis would require a tax increase equal to doubling the personal income tax or to raising the payroll tax from the current 15.3 percent of covered wages ${ }^{3}$ to more than 35 percent even if the higher tax rates did not shrink the tax base. While reductions in retirement pensions and improvements in the efficiency of the health care system could modulate this increase, any plausible level of health and retirement benefits would still require very burdensome tax rates that would greatly increase the distortions and deadweight loss of the overall tax system. ${ }^{4}$

${ }^{2}$ See Congressional Budget Office (1996), p. 78. The projected Social Security costs are based on the "intermediate" assumption of the Social Security actuaries that many experts believe understate future program costs. The projected rise in health care costs is also based on relatively optimistic assumptions, particularly the assumption that the health care costs per Medicare enrollee will decline to the rate of increase of private sector wages after 2007.

${ }^{3}$ Covered wages are currently wage and salary income up to $\$ 65,400$ (in 1997), an amount that is indexed with a lag to changes in the average level of covered wages.

${ }^{4}$ The deadweight loss of the payroll tax is the result of changes in labor supply broadly defined (including not only labor force participation and hours but also such things as individual effort and risk taking, education, choice of occupation, and choice of location) and changes in the form of compensation (substituting fringe benefits and enhanced working conditions for taxable cash). 
The obvious solution to this problem is for individuals to prefund these expenditures of old age with a system of mandatory saving accounts. ${ }^{5}$ Although the life-cycle model of rational individual behavior implies that individuals would do such saving for themselves on a voluntary basis if the government did not provide the current universal benefits for old age, in reality some individuals would not save adequately for their old age, either because of simple short-sightedness or because they explicitly decide to consume all of their earnings during their workings years and then to rely on whatever means-tested public and private assistance would be available after retirement. ${ }^{6}$ Mandatory individual accounts would, in effect, approximate what individuals would rationally choose to do if they had adequate foresight and were not diverted by the possibility of a means-tested transfer. ${ }^{7}$

The present paper examines the basic economics of replacing the existing pay-as-you-go system with such mandatory individual funded accounts. The primary focus is on Social Security

The deadweight loss of the personal income tax also reflects tax-induced changes in the timing of consumption. The increased deadweight loss due to higher tax rates can therefore be large even if there is no change in working hours or in the rate of saving. See Feldstein (1995b, 1997 and 1978).

${ }^{5}$ Many countries have shifted to such a system or are considering doing so. These include Argentina, Australia, Chile, Japan, Mexico and the United Kingdom. Sweden has recently made a step in that direction. For further information on the systems in several of these countries, see Feldstein (1996b).

${ }^{6} \mathrm{The}$ is, of course, an enormous literature on the effect of Social Security on saving for retirement. For a recent comment on this work, see Feldstein (1996a).

${ }^{7}$ Because individuals differ in their tastes, circumstances, and life expectancy, a system of mandatory individual accounts can at best be right "on average" and not for each individual. Mandatory saving accounts therefore involve some inefficiency even if the average level is set correctly. The theoretical alternative of means tested benefits would, however, also involve distortions to saving and labor market behavior. An examination of these options lies beyond the scope of the current paper. 
pensions but section 8 extends this to health benefits for the aged.

Although we have emphasized the term "prefunding" and avoided the term "privatize" in this introduction, the system of individual accounts that we discuss in this paper can be described as "privatizing" Social Security. We regard a system as effectively privatized if benefits are based on defined contribution accounts invested in private securities with the investments controlled by the individuals themselves. ${ }^{8}$ The current paper emphasizes the advantage of prefunding and does not deal with other aspects of privatization like the matching of investments to individual preferences and avoiding the problems of politicization that could come with greater government control.

\section{The Long-term Outlook for Social Security and Medicare.}

Much of the popular discussion and political concern about the outlook for Social Security and Medicare focuses on the projected "bankruptcy" of the system. These programs are now in surplus, taking in more in earmarked payroll taxes than they spend on benefits, thus reducing the overall federal budget deficit. But by the year 2015, according to the government actuaries, Social Security benefits will exceed the payroll tax receipts. The program will be in deficit and that deficit will exacerbate the overall deficit of the federal government. At that time, the Social Security program will begin to draw down the trust fund that it has been accumulating since the early 1980 s, selling the bonds in the trust fund to the public. By the year 2030, the Social Security trust fund is projected to be exhausted.

Although the talk of looming Social Security bankruptcy has increased interest in

\footnotetext{
${ }^{8} \mathrm{We}$ recognize that some would reject the "privatize" label in this case because the government specifies the amount of the annual contributions and restricts the post-retirement payouts.
} 
fundamental reform, the notion of bankruptcy has no economic meaning in this context. The Social Security and Medicare programs are said to be potentially bankrupt because they use earmarked taxes and a trust fund. Other federal programs like education and defense have no earmarked taxes and no trust fund and therefore cannot be seen as insolvent or bankrupt. Moreover, the trust fund is simply an accounting convention. Once benefits begin to exceed receipts, the Social Security program must borrow from the general public. The trust fund permits selling bonds that have in principle been previously set aside for this purpose. But the economic impact of the Social Security deficit would be the same after 2015 whether or not such a fund exists.

Because of the large size of the projected deficits in Social Security and Medicare, the accumulating debt and resulting debt service under current law would grow rapidly, placing an impossible burden on future generations. The implication of these deficits has been highlighted by the generational account calculations of Auerbach, Gokhale and Kotlikoff (1991). They show that, with no change in existing programs and taxes, the generations born after the current year would in the aggregate bear net tax burdens of more than 80 percent of their personal incomes. Since this net tax burden is calculated as the difference between the taxes paid and the transfer payments received by those individuals, the actual tax rates they would face would be even higher. This way of describing the implications of the current system makes it very clear that the current arrangements are simply not viable.

The calculations of the Congressional Budget Office (1996) show the same thing in a more familiar and therefore, perhaps, more transparent way by contrasting the projected primary deficits (i.e., the deficits excluding interest on the national debt) and the projected total deficits including the interest on the national debt. The basic CBO forecasts are summarized in Table 1: 
Table 1

Social Security, Health Benefits, and Projected Budget Deficits

2000

2010

2030

2050

(Percentages of GDP)

Social Security

5

5

7

7

Medicare and Medicaid

5

6

10

12

Total

10

11

18

19

Primary Deficit

$-1$

0

4

5

National Debt

51

64

157

311

Total Deficit

2

4

12

19

The primary deficit rises in parallel to the growth of the Social Security and health benefits for the aged, although at a somewhat slower rate. The primary deficits in turn cause the national debt to rise and the interest on that higher debt leads to even faster growth of the national debt. It is this explosive growth of the national debt and the resulting interest cost that explains why the burden on future generations of taxpayers rises to such high levels in the generational accounting analysis. Table 1 shows clearly that, without the increased budget cost of the entitlement programs for the aged (or with an increase of taxes sufficient to fund their growth), the primary deficit would not increase and therefore the total deficit would not be on its explosive path.

The true financial problem of the Social Security and Medicare programs is not the potential for insolvency under the existing system of earmarked taxes but the fact that, without 
fundamental reform, a major tax increase would be required to finance these programs as the population ages. The shift to a system of funded benefits based on individual accounts would avoid such a tax increase. As the analysis in the next section shows, the contributions to such accounts would be very much smaller than the taxes needed in a pay as you go system. Moreover, because those contributions would be directly linked to the benefits that individuals would later receive, the distortionary effects and resulting deadweight losses would be further reduced.

\section{A Realistic Transition Path to Prefunded Social Security}

This section describes a method of shifting from the existing pay-as-you-go financing of Social Security retirement benefits to a fully prefunded system. The analysis is based on the demographic and economic predictions of the Bureau of the Census and the Social Security Administration that are described in more detail in Feldstein and Samwick (1996, section 4). We begin by describing how the funded system and the transition would look to a typical employee and then present the aggregate implications for tax rates, fund contributions, and the accumulation of the capital stock.

\subsection{The Fully Funded System in the Long-run}

In the long-run, the current pay-as-you-go (PAYGO) system would be replaced by a fully funded system in which employees over the age of 30 (and their employers) make annual contributions to IRA-type accounts that we shall refer to as Personal Retirement Accounts (PRAs). ${ }^{9}$ The funds in these accounts would be invested in the individual's choice of stocks and

${ }^{9}$ In our earlier paper (Feldstein and Samwick, 1996) we referred to these accounts as Mandatory Individual Retirement Accounts (MIRAs). We have renamed them here to avoid the mandatory label since, in principle, individuals would be able to decide whether or not they wanted to save in this way or to continue with the existing PAYGO system. 
bonds. The income and capital gains on these accounts would not be taxed at any time. In addition, the government would contribute to each account the extra corporate income tax that would be collected as a result of the increased saving. With this rebate of the estimated incremental corporate tax revenue, the accounts would earn the full pretax real rate of return of 9 percent. ${ }^{10}$ When the individual reaches retirement age, the accumulated fund would be used to buy an annuity that earns the same rate of return.

The level of the annual PRA saving in our calculations is set so that the resulting annuity equals the benefits that would be paid under the current PAYGO system. This makes it easy to evaluate the gain from prefunding by focusing just on the amounts that employees (and their employers) would pay during their working years. In an actual program, contributions would probably be set at a higher level so that some of the gain from prefunding could be enjoyed during the retirement years.

The use of a 9 percent real rate of return in these calculations deserves further comment. The real pretax return on capital in the nonfinancial corporate sector can be estimated by comparing the sum of interest, dividends, retained earnings and all corporate taxes to the replacement value of the capital stock. For the years 1960 through 1994, this averaged 9.3 percent. ${ }^{11} \mathrm{~A}$ nine percent real pretax return is also consistent with the long-term portfolio returns with which most of us are more familiar. A portfolio of 60 percent equity and 40 percent debt

\footnotetext{
${ }^{10} \mathrm{An}$ alternative analysis in which the government does not rebate the extra corporate revenue is discussed later in this section.

${ }^{11}$ See Rippe (1995). Poterba and Samwick (1995) found a value of 9.2 percent for the years 1947 through 1995 and of 8.5 percent for the more recent period when they ignored property taxes paid by corporations.
} 
(essentially the financing ratio of non-financial corporations) had a yield of about 5.5 percent over both the postwar period and the period since 1926. Since corporate taxes at the federal, state and local level take approximately 40 percent of pretax debt and equity income (Rippe 1995), a portfolio return of 5.4 percent of income corresponds to a pretax real return of about 9 percent. We return in section 7 to discuss the implications of the riskiness of this rate of return.

With a 9 percent rate of return, the employer-employee contribution to the personal retirement account in the fully funded system that would be required over the long-term to fund the benefits implied by current law would be just 2.02 percent of covered wages (instead of the 18.75 percent required in a PAYGO system. ${ }^{12}$ ) Since this figure is the result of a complex simulation embodying many economic and demographic assumptions, it is useful to consider a simple "back of the envelope" calculation that shows the plausibility of this remarkable difference. Consider, therefore, an individual who saves at age 45 (representing the midpoint of the years when the individual is working and contributing) and subsequently dissaves at age 75 (representing the midpoint of the retirement years). Over this 30 year interval, one dollar grows at 9 percent to \$13.27. In contrast, as Paul Samuelson (1958) taught the economics profession many years ago, the PAYGO system provides a return equal to the rate of growth of the taxbase, i.e., to the rate of growth of average wages plus the rate of growth of the number of labor force participants. Using the 1.1 percent growth rate of GDP assumed for the long-run by the Social Security actuaries ${ }^{13}$

\footnotetext{
${ }^{12}$ The 18.75 percent is our estimate (see Table 2) but replicates the calculations of the Social Security Administration.

${ }^{13}$ See Committee on Ways and Means, 1996, page 69. Such a low long-term rate of GDP growth may seem surprisingly low relative to the 3.1 percent growth over the past four decades. But the recent decades have been characterized by several trends (a rapid growth of working age population; increases in female labor force participation; and the rise in educational attainment)
} 
implies that one dollar of PAYGO contributions at age 45 produces benefits of $\$ 1.39$ at age 75 . For every dollar of tax that must be paid in a PAYGO, a fully funded system requires only $1.39 / 13.27=0.105$ dollars. Thus an 18.75 percent payroll tax could be replaced by a 1.97 percent of payroll contribution to a Personal Retirement Account. This calculation produces a result that is remarkably close to the 2.02 percent PRA contribution calculated with our much more elaborate model.

If the government does not rebate the incremental corporate tax revenue that results from the additional PRA saving, the rate of return on the PRA accounts would be 5.4 percent. In the long run this would require PRA contributions of 5.67 percent of payroll, significantly higher than the 2.02 percent of payroll with the full 9 percent rate of return but still very much lower than the 18.75 percent tax with the PAYGO system. Of course, the government would have the extra 3.6 percent of the accumulated PRA balances in new tax receipts with which to reduce other taxes or to increase other government spending. ${ }^{14}$

In section 7 we discuss the uncertainty of the portfolio return on the assets in the Personal Retirement Accounts and show that individuals can be virtually certain (i.e., a probability greater than 0.99 ) to receive at least as much from a funded annuity as they would have in Social Security benefits if they contribute less than three percent of covered earnings instead of the 18.75 percent

that cannot continue indefinitely. Although we know of no other careful forecasts stretching 75 years into the future, it is interesting that the 25 year forecast by Data Resources shows GDP growth declining gradually to 1.4 percent in 2020 .

${ }^{14}$ The 5.4 percent rate of return would be the full national rate of return on the PRA saving if that saving replaced foreign capital in the US or would itself be invested abroad. The well-known Feldstein-Horioka (1980) evidence on the segmentation of the global capital market implies that this is not the relevant case. 
payroll tax that would be required in the PAYGO system. Until section 7 we ignore risk in our calculations.

\subsection{The Basic Transition Process}

The prospect of making a very low contribution to a PRA instead of paying a much higher payroll tax in a PAYGO system is obviously very appealing. An important practical consideration, however, is the nature of the transition from the existing system to this long-run steady state. A common concern is that the transition generation must "pay twice," i.e., must continue to pay for the existing retirees while also saving for their own retirement. Since the Social Security payroll tax (excluding the Medicare portion) is now 12.4 percent of covered wages, this appears to imply that the current generation would be required to pay more than 24 percent. Fortunately that perception is false.

Consider for example the following simple method of phasing in a prefunded system by extending it to one annual birth cohort each year: the current 30 year olds begin prefunding their retirement in year one of the transition; they are joined in year two by those who then are 30 years old; etc. It is clear that the "extra tax" that this transition generation would have to pay (in addition to the regular PAYGO tax) would be the two percent of payroll required to fund their own retirement on the assumption that they would receive no PAYGO benefits.

Such a transition is of course very slow and denies the benefits of prefunding to everyone who is over the age of 30 at the time that the transition begins. Because prefunding is introduced so slowly, the present value of the benefit of the transition is less than it could be with a more rapid phase-in. A variety of alternative transition paths is possible. We have selected one to explore that we think combines a moderate pace of phasing in with a relatively low maximum "extra" 
contribution rate that starts at only 2.0 percent of payroll and then declines.

Before we analyze this particular transition path to a prefunded system, it is helpful to consider a simpler and more rapid transition in which there is no phase-in but instead an immediate and complete shift to the funded system for all employees. Retirees continue to receive their PAYGO benefits and those employees who have contributed PAYGO taxes in the past continue to receive corresponding PAYGO benefits when they retire. For those who are over age $30^{15}$ when the transition begins, the funding contributions are set so that the combination of their prefunded annuity and the PAYGO benefits will equal the Social Security benefits provided in current law.

During the transition to a fully funded system, each employee (and his/her employer) would continue to make payroll tax payments. The amount of the PRA contribution would be taken as a credit against a total payroll tax obligation, thereby making it "costless" to the individual to contribute the necessary amount to the PRA. The total payroll tax rate would be set in each year so that the net payroll tax available after subtracting the PRA contributions would fund the existing Social Security obligations. ${ }^{16}$

Consider first those individuals who are less than 30 years old when the transition begins. Since an employee at age 30 is now deemed to have accrued no rights to future PAYGO benefits, ${ }^{17}$

15

We focus on age 30 because current Social Security rules base benefits on the taxes paid during the 35 years of highest earnings, typically between 30 and 64 . We therefore assume that individuals do not contribute to the prefunded accounts until they reach age 30 .

${ }^{16}$ Initially the payroll tax rate would be the sum of 12.4 percent and the required aggregate PRA contributions. When the trust fund is exhausted, the total payroll tax rate would be set as the sum of the tax required to meet the remaining PAYGO obligations and the required aggregate PRA contributions.

${ }^{17}$ See footnote 15. 
as each birth cohort reaches age 30 , each individual in that age group would contribute to his or her PRA an amount that, accumulating at 9 percent, would finance an annuity at age 65 (also with a yield of 9 percent) that produces the same benefits as would have been provided by the Social Security system under existing law. The annual contribution rate of this group would remain constant as they age; i.e., they would buy their retirement annuities with a "level premium as a percent of wage." This group would receive no PAYGO benefits when they retire.

Those employees who are older than 30 when the transition begins would also contribute to PRAs but at retirement would receive a mixture of PAYGO benefits and PRA annuity payments. Their PAYGO benefits would be based on the payroll taxes that they had paid during the years before the transition to the funded system began. ${ }^{18}$ The gap between these PAYGO benefits and the benefits that they would receive in the existing unfunded system would be filled by the PRA annuity. There would be no change in their combined PAYGO plus PRA benefits. The only thing that changes is the source of the benefits. The PRA contributions would be set so that, with a 9 percent real return, they would provide the required level of annuity payments.

This method of calculating each individuals's PRA contribution means that during the transition the PRA contribution rate depends on the individual's birth cohort. A 55 year old, for example, would contribute 3.52 percent of his covered earnings while a 40 year old could

\footnotetext{
${ }^{18}$ The rate of return imputed to these payroll tax payments would be the rate of return that individuals in their birth cohort would expect to receive on their lifetime tax payments in the existing unfunded system. Although the long-term implicit rate of return is the Samuelsonian growth of the tax base, the actual rate of return varies by birth cohort. We use an updated version of the estimated rates of return derived by Boskin, Kotlikoff, Puffert and Shoven (1987) that we have described in Feldstein and Samwick (1996), section 4.3. This implicit return declined from 7.0 percent among individuals born before 1915 to less than 1.5 percent among individuals born after 1960.
} 
contribute 2.05 percent. Since these PRA contributions would be credited against the individual's total payroll tax liability, these differences in PRA contributions would not translate into differences in total obligations. The payroll tax rate would instead be adjusted uniformly for everyone.

\subsection{A Gradual Phase-in to a Fully Funded System}

The transition path that we have analyzed in detail involves a gradual phased introduction to the funded system over a 25 year period. The basic idea of this gradual phase-in is to start with PRA contributions that are 25 percent of the basic amount (i.e., the amount called for in the immediate phase-in described in section 2.2) and to increase that fraction by 3 percentage points a year until it reaches 100 percent at the end of 25 years. ${ }^{19}$ Thus, each cohort of new employees reaching age 30 continues to participate to some extent in the PAYGO system until the final cohort that reaches age 30 in the $25^{\text {th }}$ year after the transition begins. Only after the $25^{\text {th }}$ year of the transition do the new 30 year olds cease to accrue PAYGO benefits and only after 60 years do new retirees come to depend wholly on their PRA annuities.

Note that the this procedure permits maintaining the same benefit payments to existing retirees and the same path of the trust fund (and therefore of the government debt) as under the existing PAYGO program. The incremental payroll tax is fully offset by the credits for "voluntary" contributions to the PRA accounts.

${ }^{19}$ Since each birth cohort pays a level percentage of its earnings, this leads to a phase in by birth cohort. The oldest birth cohort (those who are 64 in the first year of the transition) contribute only 25 percent of the full amount. Those who are 63 years old in the first year contribute an appropriately weighted average of 25 percent and 28 percent of their earnings for two years before retiring. Those who are 62 contribute approximately 28 percent of their earnings (an appropriately weighted average of 25 percent, 28 percent and 31 percent) for the three years before they retire. 
Our calculations (based on the detailed assumptions described in section 4 of Feldstein and Samwick, 1996) indicate that in the first year of this phased-in transition ${ }^{20}$ the total of all PRA contributions would be equal to 2.00 percent of payroll. ${ }^{21}$

The second year of the transition differs from the first primarily because those who become 65 have accumulated some funds in their PRAs. ${ }^{22}$ The annuity that these PRA balances generate replaces some of the PAYGO benefits. This in turn permits a smaller PAYGO tax. ${ }^{23}$

In each successive year, the number of retirees with PRA annuities increases and the average size of the annuities increases because the retirees have had more years in which to accumulate PRA balances.

The first phase of the transition is complete at the end of 25 years when all those reaching age 30 make the full PRA contribution and no longer anticipate receiving any PAYGO benefits. The second phase of the transition is complete at the end of 60 years when all new retirees have completely prefunded their retirement benefits and do not receive any PAYGO benefits. The only PAYGO benefits paid after the $60^{\text {th }}$ year are to those older retirees who were more than 5 years old when the transition began and who would therefore have earned PAYGO benefits by the taxes

\footnotetext{
${ }^{20}$ The transition is calibrated to actual demographic and economic data with 1995 as the first year of the transition.

${ }^{21}$ This 2.00 percent includes both employer and employee contributions; since this division will always be true and is of not real economic significance, we shall not refer to it again.

${ }^{22}$ The required PAYGO tax is of course affected by demographic and income changes from year to year.

${ }^{23} \mathrm{As}$ a practical matter, the annuity benefits after just one year of PRA contribution would be so small relative to the administrative costs that it would be more sensible to exclude everyone over some age (say 55) from participating in the transition. To simplify the description, we do not impose any such limit.
} 
they paid before the $25^{\text {th }}$ year of the transition.

Despite this very long phase-in, most of the adjustment occurs in the first twenty years. By year 19, the total of the PRA contributions and the payroll taxes required to meet PAYGO benefit obligations is less than the 12.4 percent payroll tax under the current PAYGO program.

Table 2 shows some of the key statistics at selected years from the first year to the $75^{\text {th }}$ year. The first row shows the baseline pay-as-you-go tax rate that would be required with no shift to prefunding. The rate continues at 12.4 percent until the trust fund is exhausted (in year 35 ) and then rises to the level required to fund benefits in each year: 16.22 percent in year 55 and 18.75 percent in year 75 .

Subsequent rows refer to the phased-in transition to the funded PRA plan (in which each retiree receives in each year a combination of PAYGO benefits and PRA annuity payments that together equal the benefits provided in current law). Row two shows the net PAYGO tax rate needed to meet the concurrent PAYGO benefit obligations. The tax rate declines gradually from 12.4 percent in the first year of the transition to 11.62 percent in year 15 and 9.23 percent in year 25. By year 55, the PAYGO tax of only 2.77 percent of payroll finances all of the concurrent benefit obligations. By the $65^{\text {th }}$ year, the PAYGO tax is less than one percent of payroll.

The third row shows aggregate PRA contributions as a percent of payroll, starting with 2.0 percent of covered earnings in year one. The PRA contribution rate then declines to a low of 1.48 percent, reflecting changes in the demographic composition and the number of years that individuals have to accumulate annuity funds. ${ }^{24}$ In the long-run, the PRA contribution is relatively

\footnotetext{
${ }^{24}$ Two principal factors are at work in determining the PRA rate in each year: the phase-in of the PRA share from 25 percent to 100 percent of the basic PRA amount raises the aggregate PRA rate while the decreasing number of individuals who begin to participate at an older age reduces
} 
stable at 2.02 percent of covered earnings. ${ }^{25}$

Table 2

Transition Path of Tax Rates, PRA Contributions and Benefits

\begin{tabular}{lllllllll}
\multicolumn{8}{c}{ Year* } \\
1 & 5 & 10 & 15 & 25 & 35 & 55 & 75
\end{tabular}

1. Tax Rate with unfunded system**

$\begin{array}{rrrrrrrr}12.40 & 12.40 & 12.40 & 12.40 & 12.40 & 12.40 & 16.22 & 18.75 \\ 12.40 & 12.35 & 12.12 & 11.62 & 9.23 & 5.29 & 2.77 & 0.20 \\ 2.00 & 1.85 & 1.69 & 1.57 & 1.48 & 1.62 & 1.93 & 2.02 \\ 14.40 & 14.20 & 13.81 & 13.18 & 10.71 & 6.91 & 4.69 & 2.23 \\ & & & & & & & \\ 0 & 1 & 10 & 29 & 135 & 338 & 813 & 1385 \\ 20.73 & 21.57 & 22.67 & 23.83 & 26.32 & 29.07 & 35.48 & 43.29 \\ & & & & & & & \\ 2927 & 3156 & 3453 & 3752 & 4273 & 4789 & 6064 & 7526\end{array}$

7. Covered Earnings (Billions of 1995 \$)

*1995 is year 1

**Percent of Covered Earnings

Row 4 combines the net PAYGO tax and the aggregate PRA contribution and shows the combined mandatory payment, starting with 14.4 percent in the first year, just two percentage points of payroll more than the current unfunded system. The excess declines gradually and the total mandatory payment drops below the initial 12.4 percent in year 19 . By the $25^{\text {th }}$ year,

the aggregate PRA rate.

${ }^{25}$ With the 5.4 percent rate of return on the PRA accounts that would be possible without the government's rebate of incremental tax revnue, the first year PRA contribution would be 3.93 percent of payroll.

Ssfund.0517 
employees are paying 1.69 percent of payroll less than they would with the existing 12.4 percent payroll tax. The favorable difference between the tax under the existing unfunded system (row 1) and the combined payments in the transition to the fully funded system then grows rapidly. By year 35, the combined PAYGO tax and PRA contribution rate is just 6.91 percent, just slightly more than half of the PAYGO tax under the current unfunded system.

Comparing rows 5 and 7 shows that PRA benefits are only about one percent of covered earnings in year 15 but rise rapidly to seven percent of payroll in year 35 and 18.4 percent of payroll in year 75 , replacing virtually all the PAYGO benefits.

\subsection{Behavioral Responses and the Size of the Tax Base}

The analysis of Table 2 does not reflect the effect of tax rates on the amount of taxable income that individuals earn. ${ }^{26}$ The existing payroll tax causes employees to reduce their labor supply (broadly defined to include effort, occupational choice, and location as well as the number of hours worked) and to substitute untaxed fringe benefits and better working conditions for taxable cash compensation. The future increase in the payroll tax rates required under the PAYGO system would cause a further reduction in taxable payroll earnings. In contrast, the shift to a prefunded system would reduce the tax distortion and cause a rise in taxable earnings.

We model these changes in taxable income as the product of an elasticity and the change in the marginal net-of-tax wage (i.e., the wage multiplied by one minus the effective marginal tax rate .) The effective marginal tax rate includes the federal and state personal income tax rates, the effective state and local sales tax rates, and the net payroll tax rate (including the portion needed

\footnotetext{
${ }^{26}$ This discussion follows the analysis previously presented in Feldstein and Samwick (1996), section 5.3 . 
to offset the PRA credits). We assume (quite conservatively) a 20 percent rate for taxes other than the payroll tax. The net payroll tax rate and the tax equivalence of the PRA contribution require more careful descriptions.

The net PAYGO payroll tax rate is the difference between the payroll tax payment $(12.4$ percent until year 2030 and then the rates shown in row 1 of table 2) and the amount that the individual would have to pay to purchase the same benefit at the rate of return available in private pensions or $401 \mathrm{k}$ plans. For example, if the payroll tax payment is 12.4 percent but the same benefits could be purchased in a private annuity for a premium equivalent to 5 percent of payroll, the net payroll tax is really 7.4 percent and the remaining 5 percent can be thought of as saving.

The cost of purchasing the same benefit privately (i.e., the analog of the 5 percent in the preceding example) is calculated as follows: if the implicit rate of return that the individual earns on the Social Security payroll taxes is denoted $\gamma$, a dollar of payroll tax paid at age a grows to

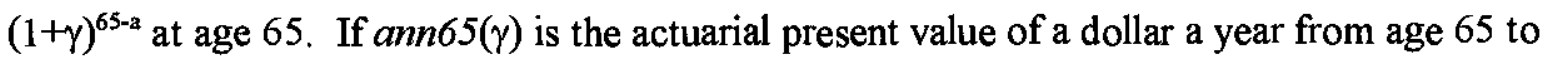
death based on a return of $\gamma$, the dollar of payroll tax paid at age a earns an annuity starting at age 65 of $(1+\gamma)^{65-a} / a n n 65(\gamma)$. To purchase the same annuity with a private pension plan that earns a return of $\mu$, an employee or employer would have to spend only $\left[(1+\mu)^{65-a} / a n n 65(\mu)\right]^{-1}$. Because pension funds do not pay tax on their income, a plausible value for $\mu$ is the return on capital net of corporate and property taxes but before all personal income taxes. A pretax real return of 9 percent and a corporate tax rate (including state and local taxes property taxes) of 40 percent imply $\mu=5.4$ percent; this is of course close to the 5.2 percent return earned on a marketweighted mix of stocks and bonds over the past four decades.

Since $\mu$ is substantially greater than $\gamma$, there is a substantial effective tax implied by the 
payroll tax. For example, since someone born in 1960 would receive a return on Social Security taxes of only $\gamma=1.39$ percent, each dollar of payroll tax could be replaced by only 21.6 cents of contribution to a private pension fund. This implies that 78.4 percent of the 12.4 percent payroll tax is a pure tax. More generally, we define the effective net payroll tax rate as $\{1-[(1+\gamma) /(1+$ $\left.\mu)]^{65-\mathrm{a}}[\operatorname{ann} 65(\mu) / \operatorname{ann} 65(\gamma)]\right\} \tau_{\mathrm{p}}$ where $\tau_{\mathrm{p}}$ is the payroll tax rate (currently 0.124$)$. Alternatively, we write the payroll tax rate as $\tau_{\mathrm{p}}-\beta$ where $\beta=-[(1+\gamma) /(1+\mu)]^{65-\mathrm{a}}[\operatorname{ann} 65(\mu) / \operatorname{ann} 65(\gamma)] \tau_{\mathrm{p}}$ is the present actual value of the benefit per dollar of incremental taxable earnings. Combining this with the marginal personal income tax rate $(\theta)$ implies a net of tax share under existing Social Security rules of $1-\theta-\tau_{p}+\beta$. We denote this $N_{0}$. For example, with $\theta=0.20, \gamma=0.0139$ and $\mu$ $=0.054$, the net of tax share for a current 35 year old is $\mathrm{N}_{0}=0.703$.

Consider now the net of tax share during the transition to a funded system. An individual who earns an additional dollar of wage income in year $t$ must then pay, in addition to income tax at rate $\theta_{\mathrm{t}},(1)$ a payroll tax at rate $\tau_{\mathrm{pt}}$ to finance the remaining PAYGO benefit obligations and (2) a payroll tax surcharge to offset the revenue lost because individuals reduce their payroll tax obligations by the amount of their PRA contributions. We denote the "Combined PAYGO Tax and PRA Contribution Rate" (shown in row 4 of Table 2) by $\tau_{\mathrm{p}}$. The individual's net-of-tax share becomes $N_{1}=1-\theta-\tau_{p}^{*}+\beta$ where $\beta$ is the same as in the current system since the value of the benefits is unchanged by switching to the PRA system. ${ }^{27}$ When the transition to the funded system

\footnotetext{
${ }^{27}$ It is tempting to ask: "What about the high return that the individual receives on his PRA contribution? Doesn't that act as a negative marginal tax that should be taken into account? For example, in the first year an individual not only pays the PAYGO tax and the PRA surcharge (14.4 percent shown in row 2 of table 2) but also contributes an amount to his PRA account which earns a high 9 percent rate of return. Shouldn't this reduce the net marginal tax rate and imply a higher net-of-tax share?" Unfortunately the answer to this is "no." Any individual who
} 
is complete and no further PAYGO benefits are being paid, the value of $\tau *_{p}$ becomes the PRA contribution rate (which, by assumption, is constant over the working life of each birth cohort.)

We assume that taxable income responds to changes in the net-of-tax share with an elasticity of $0.5{ }^{28}$ This implies that taxable income rises or falls by a factor of $\left[\mathrm{N}_{1} / \mathrm{N}_{0}\right]^{0.5}$. This in turn means that the payroll tax revenue collected by tax rate $\tau_{p}$ with the initial labor supply can be collected at a tax rate $\tau_{\mathbf{p}}^{\prime}=\tau_{\mathrm{p}}\left[\mathrm{N}_{1} / \mathrm{N}_{0}\right]^{-0.5}$. Similarly the personal income tax rate that collects the same revenue becomes $\theta^{\prime}=\theta \quad\left[\mathrm{N}_{1} / \mathrm{N}_{0}\right]^{-0.5}$.

The path of the tax rates is shown in Table 3. The first two rows compare net-of-tax shares under the existing PAYGO system (with the tax increased to maintain benefits after the trust fund is exhausted) and along the transition path. The next two rows show the payroll tax rates with no behavioral response (row 3) and with the behavioral response implied by the change in the net of tax share (row 4). Note that this is the pure payroll tax (excluding the PRA surcharge) needed to maintain the trust fund along the projected path (and at zero after it is exhausted). The personal income tax rate with behavioral response is shown in row 5 ; with no behavioral response, the rate

earns an extra $\$ 100$ in year one of the transition pays 14.4 dollars in combined payroll tax and PRA contribution but earns the same incremental benefits in retirement as would be earned under the existing PAYGO system. This individual's own PRA contribution does not affect his benefits but lowers the future PAYGO taxes of those who will be working when he retires. Participating in the transition also means that PRA contributions paid by others who are older than he will reduce his PAYGO taxes but the extent to which that happens does not depend on his own earnings.

${ }^{28}$ The relevant elasticity is not just the traditional elasticity of working hours with respect to the net-of-tax wage but includes a broader definition of labor supply (including effort, occupation, risk-taking, etc.) and the change in taxable income that comes from changes in the form of compensation. Although estimates of this elasticity with respect to changes in the income tax are between 1.0 and 1.5 for high income individuals (Feldstein 1995a; Auten and Carrol, 1994), we are dealing here with low and middle income individuals and with the payroll tax rather than the income tax. We are therefore quite conservative and assume an elasticity of only 0.5 . 
is a constant 0.20 . Row 6 shows the combined payroll and personal tax rates and the PRA contribution. The combination of the PRA contribution and the unchanged year 1 payroll tax

Table 3

Effects of Taxpayer Behavior on Tax Rates and Deadweight Loss All Rates Reflect Behavioral Response Unless Otherwise Stated

$$
\text { Percent of Covered Earnings }
$$

Year*

$\begin{array}{llllllll}1 & 5 & 10 & 15 & 25 & 35 & 55 & 75\end{array}$

1. Net of tax share in system

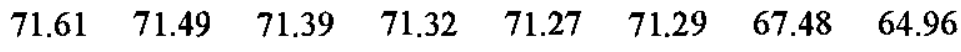

2. Net of tax share in transition to funded PRA system

$\begin{array}{llllllll}69.61 & 69.70 & 69.98 & 70.54 & 72.96 & 76.78 & 79.07 & 81.49 \\ 12.40 & 12.35 & 12.12 & 11.62 & 9.23 & 5.29 & 2.77 & 0.20 \\ & & & & & & & \\ 12.58 & 12.51 & 12.24 & 11.68 & 9.12 & 5.10 & 2.55 & 0.18 \\ & & & & & & & \\ 20.29 & 20.26 & 20.20 & 20.11 & 19.77 & 19.27 & 18.47 & 17.85\end{array}$

5. Personal Income Tax Rate with Behavioral Response

6. Combined Payroll and Personal Tax Rates with $\begin{array}{llllllll}34.87 & 34.62 & 34.13 & 33.36 & 30.37 & 25.99 & 22.95 & 20.05\end{array}$ Behavioral Response plus PRA Contribution

7. Change in Deadweight Loss (Percent of Covered Earnings)

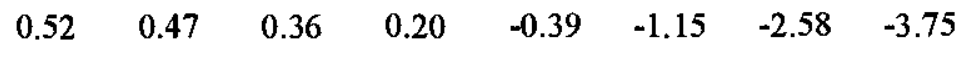

causes the net-of-tax-share to fall initially and that causes taxable earnings to decline. The effect is small and is offset by raising the payroll tax rate from 12.40 percent to 12.58 percent. Similarly, the personal income tax rate only has to be raised from 20 percent to 20.29 percent. By year 20 the increased taxable income causes the combination of the payroll tax rate (10.66 percent) and the PRA contribution (1.52 percent) to be lower than the initial 12.4 percent. By year 40 , the personal 
income tax rate is reduced from 20 percent to 19 percent. The payroll tax rate is also reduced by one-twentieth, from 7.44 percent to 7.07 percent.

The variations in the combined rates of payroll and personal income taxes (including the PRA contribution) cause changing distortions in labor markets and variations in the deadweight loss of the tax system. These changes in deadweight loss are shown in Row 7 of Table 3. We return to discuss them in section 3 .

\subsection{Effects on Capital Intensity, the Rate of Return, and the Distribution of Income}

Before considering the welfare economics of the PRA transition and the generational distribution of benefits and costs, we examine some of the macroeconomic implications of the transition to a funded system. A common criticism of calculations of the type presented in sections 2.3 and 2.4 is that they assume a fixed 9 percent marginal product of capital (MPK) when the process of capital accumulation in PRA accounts would cause the MPK to decline. We analyze that in the current section, calculating also the effect on national income and real wages of shifting to a funded system.

To achieve maximum transparency of this analysis, we begin by looking at the path of accumulated aggregate PRA balances on the assumption that nothing else is changed. This corresponds to the economic assumptions implicit in table 2. The aggregate PRA balance grows by the PRA contributions and the 9 percent return on the PRA balance and is diminished by the payment of PRA annuities. Row 1 of table 4 repeats the aggregate PRA contribution as a percentage of covered earnings. Row 2 shows the net flows into the PRA accounts, i.e., the difference between contributions and PRA annuities. This net inflow declines from the very beginning and becomes negative in the twentieth year because the earnings on the PRA balances 
are more than enough to achieve the needed growth of the PRA fund. The net "inflow" tends toward a long-run "permanent" level of minus 16 percent of payroll when the gross inflow is about 2 percent of payroll and the benefits are equal to about 18 to 19 percent of payroll. Aggregate PRA balances as a fraction of payroll are shown in Row 3, increasing from the initial 2 percent of payroll to 100 percent of payroll

Table 4

Effects of Personal Retirement Account Accumulation on the Capital Stock and the Marginal Product of Capital

Year*

1. PRA Contributions (Percent of Payroll)

2. Net Inflow to PRA Accounts (Percent Of Payroll)

3. Aggregate PRA Balance (Percent Of Payroll)

4. Percentage Increase In Capital Stock

5. Marginal Product Of Capital

6. Percentage Increase In Real Wage Rate

7. Percentage Increase In Real Disposable Wage

$\begin{array}{llllllll}1 & 5 & 10 & 15 & 25 & 35 & 55 & 75 \\ 2.00 & 1.85 & 1.69 & 1.57 & 1.48 & 1.62 & 1.93 & 2.02 \\ & & & & & & & \\ 2.00 & 1.80 & 1.41 & 0.79 & -1.66 & -5.43 & -11.48 & -16.37 \\ 2 & 11 & 25 & 41 & 82 & 123 & 188 & 230 \\ & & & & & & & \\ 0.30 & 1.63 & 3.70 & 6.07 & 12.14 & 18.20 & 27.82 & 34.04 \\ & & & & & & & \\ 8.98 & 8.89 & 8.76 & 8.61 & 8.26 & 7.94 & 7.49 & 7.22\end{array}$

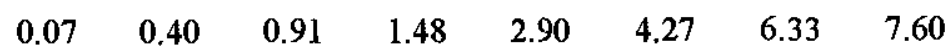

$\begin{array}{llllllll}-2.89 & -2.27 & -1.19 & 0.31 & 5.48 & 12.74 & 25.55 & 36.62\end{array}$

* Year 1 corresponds to 1995 in the underlying demographic and economic data.

in year 28 percent and to 2.3 times payroll in the long run.

To understand the possible effect of the accumulating PRA assets on the marginal product of capital, we calculate the percentage change in the capital stock that would occur if the capital 
stock rises dollar for dollar with the aggregate PRA balance. To estimate the baseline capital stock under the existing PAYGO system, we assume that the current ratio of covered earnings to GDP remains unchanged at 0.40 and that the current ratio of the GDP to the capital stock remains unchanged at 0.37 . These assumptions imply that the baseline capital stock is 6.76 times covered payroll. Comparing the aggregate PRA balances in row 3 to this baseline capital stock implies the potential rise of the capital stock shown in row 4: 12 percent in year 25, 28 percent in year 55 and an essentially stable 34 percent after the $75^{\text {th }}$ year. With a Cobb-Douglas technology and a capital share of 0.25 , the marginal product of capital declines from 9.0 percent with the existing capital stock to 8.3 percent in year $25,7.5$ percent in year 55 and 7.2 percent in year 75 .

Thus even with the assumption that PRA assets add dollar for dollar to the capital stock, the decline in the marginal product of capital in the very long run is only from 9 percent to 7.2 percent. Substituting a 7.2 percent rate of return for a nine percent return (for the entire transition period) only raises the long-run contribution rate from 2.02 percent of payroll to 3.40 percent of payroll, still less than one-fifth of the long-run PAYGO tax rate.

The increase in the capital stock shown in row 4 and the Cobb-Douglas technology imply that the real wage rate is 2.90 percent higher in year 25 and 7.60 percent higher in the very long run. These are shown in row 6 of Table 4 . These are of course also the proportional increases in the real GDP.

Although the assumption of the Cobb-Douglas technology implies that the shares of capital and labor in GDP remain unchanged, there is a substantial redistribution of capital income. All of the extra capital income is dedicated to paying retirement benefits on wages up to the about the $90^{\text {th }}$ percentile of the wage distribution. The decline in the rate of return depresses the capital 
income of the owners of "old capital." Since this "old capital" is generally owned by those with higher incomes, the shift to a funded system would involve a one-time market driven redistribution from old capital owners to workers and an on-going decline in the return that higher income individuals get on their savings.

It is interesting to combine the real income and tax rate effects to calculate the full effect of the shift to a funded system on the disposable income of employees. With the current PAYGO system, the combination of the 20 percent income tax and the long-run payroll tax of 18.75 percent implies that a pretax income of 100 produces disposable income of 61.25 . With the fully funded system, the pretax income is increased to 107.6. If the PRA contribution of 3.40 percent replaces the PAYGO tax of 18.75 percent, disposable income rises from 61.25 to 82.45 , an increase of more than one-third ${ }^{29}$ The time path of such increases is shown in row 7 of Table 4 . Note that the assumptions of the calculation imply that the retirement income would increase by the same proportion as the real wage, i.e., by 7.6 percent in the long-run. It would of course be possible to reduce consumption during the working years to balance the increases in retirement and preretirement consumption.

\subsection{Endogenous Response of Personal Saving Behavior}

In the early part of the transition, individuals experience a decline in lifetime income

${ }^{29}$ This calculation assumes the value of the PRA contribution that would prevail in the long-run when all PAYGO retirees are gone and when the increased capital stock reduces the marginal product of capital to 7.2 percent. The corresponding figure for year 75 in row 7 of Table 4 is based, like all of the other figures in Table 4 , on the assumption of a 9 percent rate of return (and therefore a PRA contribution of only 2.02 percent.) A different possibility for year 75 would be to recognize that some PAYGO benefits must still be financed; with a 7.2 percent marginal product of capital and PAYGO benefits of 0.20 percent of payroll, the 18.75 percent PAYGO tax would be replaced by a combination of PRA contribution and PAYGO tax of 3.61 percent; even in this case, the real disposable income would rise by 34 percent. 
because the sum of the payroll tax and the PRA contribution rises while benefits remain unchanged. Later in the transition and in the long run, individuals have higher lifetime incomes because the PRA replaces the higher payroll tax. Traditional rational life-cycle saving behavior would imply that people respond to their reduced disposable income by cutting saving in order to spread the reduction in consumption to retirement years.

In fact, however, American households generally do not have the financial assets with which to reduce their saving. Even for those near retirement, the median financial assets is less than one-half of a year's earnings. We have therefore chosen to ignore the potential response of saving to changes in current and future taxes.

Of course, as the transition is completed, the rise in lifetime incomes implies that individuals would want to save more during their working years to raise the level of retirement consumption. We also do not take this into account.

\section{The Welfare Economics of Funding Social Security Benefits}

When the transition from a PAYGO system to a funded system of financing a given set of retirement benefits has been completed, each birth cohort is better off in two important ways. First, the PRA contributions require a much smaller annual payment than the corresponding PAYGO payroll tax to finance the same benefits. This is a first order effect that would exist even if the existing PAYGO tax did not cause a deadweight loss by distorting economic decisions. Second, substituting the smaller PRA contributions for the much higher PAYGO tax reduces the deadweight loss that results from distortions to labor supply and to the form of compensation. This is also a first-order effect because the payroll tax is incremental to the personal income tax, implying that the resulting deadweight losses are first order "trapezoids" rather than second order 
triangles. $^{30}$

These permanent long-run gains are paid for in part by temporary increases in taxes and in deadweight burdens on the birth cohorts in the labor force during the early part of the transition. This section discusses the path of changes in tax payments and deadweight losses and presents alternative present value calculations.

The dollar values of the annual changes in the deadweight loss are estimated using the traditional Harberger-Browning approximation: $\Delta \mathrm{DWL}=0.5 \varepsilon\left[\mathrm{t}^{2}{ }_{0}-\mathrm{t}^{2}{ }_{1}\right]\left(1-\mathrm{t}_{0}\right)^{-1} \mathrm{E}$ where $\mathrm{E}$ is the current payroll tax base, $\mathrm{t}_{0}=1-\mathrm{N}_{0}=\theta+\tau_{\mathrm{p}}-\beta$ (the marginal tax rate with the existing system) and $t_{1}=1-N_{1}=\theta+\tau *_{p}-\beta$ (the marginal tax rate with the PRA system and in the transition). These values are presented in row 7 of Table 3 .

At first, the increase in the combined payroll tax and PRA contribution raises the annual deadweight loss of the tax system. In the first year, the increase is 0.52 percent of covered wages. Individuals are thus worse off in the first year both because they are paying 2.00 percent of their wages in additional mandatory contributions (as shown in row 3 of Table 2) and because doing so increases the deadweight loss by 0.52 percent of payroll. The PRA surcharge and the deadweight loss then decline rapidly. The extra deadweight loss is halved by year 13 and is completely gone by year 18. By year 25 , the lower combined value of the payroll tax and the PRA contribution $\left(\tau *_{\mathrm{p}}=\right.$

\footnotetext{
${ }^{30}$ There is a third effect on employees; the increased capital stock that results from the accumulating PRA balances raises the marginal product of labor and therefore the real wage of employees. However, since this is (to a first order approximation) balanced by a decline in the return on the existing capital stock, we ignore this rise in wage income. More formally, with no induced change in labor in each year $Y=f(K, L)$ implies $d Y=f_{K} d K=r d K$. Allowing for second order effects (on factor prices) implies $d Y=r d K+K d r+L d w$ since $d L=0$. Thus $L d w=-r d K$ and these two effects can be ignored in evaluating the change in national income.
} 
0.1071 as shown in Row 4 of Table 2 , instead of $\tau_{p}=0.124$ ) reduces the year's deadweight loss of the tax system by 0.39 percent of covered wages; the individuals' total burden in financing retirement consumption is thus down by 2.08 per cent of covered wages.

By year 55, the combination of the payroll tax and the PRA contribution is down to just 4.69 percent (vs an otherwise required PAYGO contribution in that year of 16.22 percent) and the resulting reduction in the deadweight loss is 2.58 percent of earnings, implying a total reduction in the net burden equal to 14.11 percent of wages.

Note particularly that by the $75^{\text {th }}$ year the total cost of financing the retirement benefits is only 2.23 percent of wages while the reduced deadweight loss associated with the reduced cost of financing is 3.75 percent of wages. Thus the reduced deadweight loss is more than enough to pay for the entire PRA contribution. The net gain to the individual is thus more than 20 percent of covered payroll: the shift from the 18.75 percent projected payroll tax to the combined payroll tax residual (of 0.20 percent of payroll) and the PRA contribution ( of 2.02 percent), a gain of 16.52 percent of payroll, plus the associated 3.75 percent of payroll reduction in the deadweight loss associated with labor market distortions.

Table 5 shows the estimated present values of the gains from shifting to funded retirement benefits. The analysis distinguishes the present value of the reduced tax and PRA contributions (row 1) and the reduced deadweight loss (row 2). The present value calculations take into account not only the difference in the tax rate $\left(\tau_{p}-\tau_{p}\right)$ but also the growing level of taxable earnings (E). Thus the present value of the increased spendable income that results from the transition to a funded system with unchanged benefits is: $\Sigma\left(\tau_{p}-\tau *_{p}\right) E_{t}(1+\delta)^{-t}$ where $E_{t}$ is the level of aggregate taxable earnings and $\delta$ is the discount rate. Similarly the present value of the 
changes in the deadweight losses is $\Sigma \Delta \mathrm{DWL}_{\mathrm{t}}(1+\delta)^{-t}$ where the annual change in the deadweight loss $\left[\Delta \mathrm{DWL}=0.5 \varepsilon\left[\mathrm{t}^{2}{ }_{0}-\mathrm{t}^{2}{ }_{1}\right]\left(1-\mathrm{t}_{0}\right)^{-1} \mathrm{E}\right]$ is discussed above. The discounting is to 1995 , the first year of the transition and the discounted values are stated in both 1995 dollars and as percentages of covered earnings in 1995.

The appropriate rate of discount should reflect the rate at which the marginal utility of additional consumer income declines over time as incomes rise. A projection that real per capita income will rise at about 1 percent a year suggests a discount rate of 2 percent (if the elasticity of the marginal utility function is taken to be two) or 3 percent (if the elasticity of the marginal utility function is taken to be 3 ). Results are also presented in Table 5 for a discount rate of 4 percent. ${ }^{31}$ Although numerical simulation results are available for only 75 years, the gain from shifting to a funded program continues beyond that time. Without the shift, the heavy burden of financing retirement income by a high payroll tax, and the associated deadweight loss would continue indefinitely. To estimate the present value of the gain associated with the period after the first 75 years, we assume that without the shift the PAYGO tax rate projected for year 75 under the existing system (18.75 percent of covered wages) would continue indefinitely after that date while with the shift to a funded system the benefits after year 75 would continue to be financed with a PRA contribution of 2.02 percent of covered wages (the projected value for year 75 ). If aggregate wages grow at $g$ percent a year after year 75 and the benefits of funding are discounted at rate $\delta$,

\footnotetext{
${ }^{31} \mathrm{~A}$ discount rate of 4 percent would of course correspond to a marginal utility elasticity of two if the rate of growth of real per capita income were two. While this was the case in the past and frequently led to the choice of a discount rate of 4 percent, the lower real growth rate now projected for the future implies that the discount rate should be reduced accordingly. See footnote 13 .
} 
the present value of the reduced payments is:

$$
V_{1}=(1+\delta)^{-74}\left(\tau_{p}-\tau_{p}^{*}\right) E_{75} \Sigma_{1}[(1+g) /(1+\delta)]^{t}
$$

where the summation is from $t=1$ to $t=\infty, \tau_{p}$ is the long-run PAYGO tax rate of 18.75 percent, $\tau *_{p}$ is the long-run PRA contribution rate of 2.02 percent, and $E_{75}$ is the aggregate level of covered wages in year 75 ( $\$ 7526$ billion in 1995 dollars). Similarly the present value of the deadweight loss reductions after year 75 is

$$
\mathrm{V}_{2}=(1+\delta)^{-74} 0.5 \varepsilon\left[\mathrm{t}^{2}{ }_{0}-\mathrm{t}^{2}{ }_{1}\right]\left(1-\mathrm{t}_{0}\right)^{-1} \quad \mathrm{E}_{75} \Sigma_{1}[(1+\mathrm{g}) /(1+\delta)]^{\mathrm{t}}
$$

Using the Social Security actuaries' prediction that the growth rate of aggregate wages in the middle of the twenty-first century will be only about 1.1 percent a year implies the $V_{1}$ values shown in row 1 of table 5 .

With the three percent discount rate, the overall present value gain from shifting to a funded system is $\$ 16.6$ trillion at 1995 prices. Most of this net gain (about 80 percent) is the result of the "reduced tax" (i.e., reduced cost of funding retirement benefits) while the remainder is the reduction in the deadweight loss. About half of the present value gain is associated with the first 75 years and the remainder with the years that follow. A 4 percent discount rate cuts the gain from funding approximately in half but still leaves a very large $\$ 7.1$ trillion present value gain with 60 percent of that gain in the first 75 years. As the discount rate approaches the growth rate, the gain becomes explosively large; this is seen with a discount rate of two percent implying a welfare gain from funding of more than $\$ 50$ trillion.

The important implication of these calculations is that even though the combined payroll 
Table 5

Present Value of Deadweight Loss Reductions

Discount Rate

$$
2 \text { percent }
$$

3 percent

4 percent

Years

$1-75 \quad 75+\quad$ All

$1-75 \quad 75+\quad$ All

$1-75 \quad 75+\quad$ All

Billions of $1995 \$$

1. Reduced tax

$$
\begin{array}{lll}
10385 & 32672 & 43057
\end{array}
$$

$\begin{array}{lll}5890 & 7518 & 13408\end{array}$

$3344 \quad 2410 \quad 5754$

2. Reduced DWL

$\begin{array}{lll}2343 & 8104 & 10447\end{array}$

$1324 \quad 1865 \quad 3189$

$\begin{array}{lll}746 & 598 & 1344\end{array}$

3. Total Gain

$12728 \quad 40776 \quad 53504$

721

9383

16597

$\begin{array}{lll}4090 & 3007 & 7097\end{array}$

Percent of 1995 Covered Wages

1. Reduced tax

355

$1116 \quad 1471$

$201 \quad 257$

458

$114 \quad 82$

196

2. Reduced DWL

$\begin{array}{lll}80 & 277 & 357\end{array}$

$\begin{array}{lll}45 & 64 & 109\end{array}$

$25 \quad 20$

45

3. Total Gain

435

$1393 \quad 1828$

$\begin{array}{lll}246 & 321 & 567\end{array}$

$139 \quad 103$

242

tax and PRA contributions have to rise in the early decades of the transition, the present value of the net gains and losses is clearly a very substantial positive value.

\section{Net Gains by Birth Cohort and the Possibility of a Pareto Improving Transition}

The essential feature of the transition to a funded program of retirement benefits is a period of reduced consumption by employees during the early years of the transition so that a dedicated capital stock can be accumulated. This dedicated capital is then used to finance retirement benefits, thereby permitting lower taxes and more consumption by employees in later years.

With the specific very gradual transition path studied in sections 3 and 4 , the combination of the PRA contributions and the payroll taxes remains higher than the 12.4 percent payroll tax rate in the pure PAYGO program for 18 years. Anyone who is at least 47 years old when the 
transition begins will pay more under our calculations than he would with the existing PAYGO system. $^{32}$

For younger cohorts, there will initially be higher taxes-plus-PRA-contributions followed by lower payments. These changes in the combined tax and PRA rates affect real net incomes directly and also by the associated changes in deadweight losses. The time path of net losses followed by net gains is presented in Table 6 for three age cohorts, identified by their age in the first year of the transition (1995). Each figure in the table shows the net gain or loss, including the

Table 6

Time Path of Net Gains by Different Age Cohorts

Year*

1

$5 \quad 10$

15

20

25

30

35

40

Age in first year of transition

55

40

25

\begin{tabular}{lllllllll}
\hline-2.44 & -2.17 & -1.68 & 0 & 0 & 0 & 0 & 0 & 0 \\
-2.52 & -2.25 & -1.75 & -0.96 & 0.27 & 1.99 & 0 & 0 & 0 \\
-2.62 & -2.36 & -1.79 & -0.99 & 0.28 & 2.06 & 4.23 & 6.45 & 8.62
\end{tabular}

associated change in deadweight loss as a percentage of taxable wages. The 55 year olds have a small net loss in each preretirement year. The forty year olds have gradually decreasing losses for 18 years and then gradually increasing gains. The 25 year olds are required to pay a higher payroll tax in the early years even though they are not making PRA contributions until the fifth year. After 18 years of higher contributions they enjoy the benefit of rising gains that reach more than 8

\footnotetext{
${ }^{32}$ This rests on the critical assumption that if the PAYGO system continues there would be no adjustment in taxes during the next 18 years and no reduction in benefits after that time but an increase in taxes (after 2030) to maintain the existing benefit rules. If either assumption is violated, individuals who are 47 years old or older may be better off with the PRA transition than in the pure PAYGO system.
} 
percent of their wages before they finally retire at age 65 .

Although the shift to a funded system is unambiguously a "bad deal" for the 55 year olds (assuming that the alternative is to leave taxes and benefits unchanged until 2030), the effect for the other age cohorts depends on the rate at which they discount future real income changes. Table 7 presents the actuarial present values of the net gains for birth groups classified by their age at the time that the transition begins. Results are presented for four real discount rates from zero through 6 percent. The first part of the table (rows 1 through 3 ) shows the actuarial present values in thousands of 1995 dollars. The second part of the table restates those present values as percentages of the present actuarial value of the individual's future earnings.

Table 7

Actuarial Present Values of Net Gains by Age at the Start of the Transition

$\begin{array}{lllllllllll}\text { Age at Start } & 5 & 10 & 15 & 20 & 25 & 30 & 40 & 50 & 55 & 60\end{array}$

Thousands of Dollars

per Worker (\$1995)

Discount Rate

\begin{tabular}{|c|c|c|c|c|c|c|c|c|c|c|}
\hline Zero & 104.85 & 77.27 & 53.03 & 32.33 & 16.37 & 4.97 & -5.79 & -5.73 & -4.06 & -2.09 \\
\hline $2 \%$ & 43.37 & 33.70 & 23.81 & 14.11 & 6.40 & 0.58 & -5.46 & -5.13 & -3.75 & -2.01 \\
\hline $4 \%$ & 18.88 & 15.23 & 10.73 & 5.54 & 1.51 & -1.61 & -5.09 & -4.64 & -3.49 & -1.94 \\
\hline $6 \%$ & 8.64 & 7.10 & 4.73 & 1.47 & -0.88 & -2.65 & -4.73 & -4.22 & -3.25 & -1.87 \\
\hline
\end{tabular}

Percent of Future Wages

(Actuarial Present Value)

Discount Rate

$\begin{array}{ccccccccccc}\text { Zero } & 8.28 & 6.40 & 4.60 & 2.93 & 1.65 & 0.58 & -1.01 & -1.87 & -2.11 & -2.28 \\ 2 \% & 7.20 & 5.31 & 3.57 & 2.00 & 0.95 & 0.09 & -1.18 & -1.91 & -2.13 & -2.28 \\ 4 \% & 6.15 & 4.28 & 2.60 & 1.16 & 0.31 & -0.34 & -1.34 & -1.95 & -2.14 & -2.28 \\ 6 \% & 5.19 & 3.35 & 1.75 & 0.43 & -0.24 & -0.72 & -1.49 & -1.98 & -2.15 & -2.28\end{array}$

Except for those who are too young to be working when the transition begins, the effect of 
the shift to a funded system is relatively small. With a discount rate of four percent, the present actuarial value of the net loss is greatest for the 40 year olds but their lifetime loss (expressed as an actuarial present value ) is only about $\$ 5,000$ or about 1.3 percent of their future wage income.

For the very young, the favorable changes are much larger: with a four percent discount rate, the net gain to those who are 10 when the transition begins has a present actuarial value of $\$ 15,230$ or about 4.3 percent of future wages.

Although those who are 40 or older are net losers in the transition, the result is quite different if we look at the nuclear family. Combining a husband and wife age 40 with two children below age 20 shows a very large gain to the family.

\subsection{The Possibility of a Pareto Efficient Transition to a Funded System}

Different phase-in schedules can reduce the number of age groups that are net losers; the simplest example is a transition that leaves employees over some age in the existing PAYGO system. A more interesting question is whether it is possible to structure the transition in such a way that all cohorts gain.

The difficult problem in designing a Pareto improving transition to a funded system is to accumulate funds that can be used to finance future retirement benefits (and therefore to reduce the future PAYGO tax) without making at least one birth cohort permanently worse off in the process. The following example shows that it may be possible to have such a Pareto efficient transition to a fully funded program. This transition path is not put forward as optimal or as better than the basic example of section 2 or even as a realistic option but only to show that a Pareto efficient transition 
is theoretically feasible. ${ }^{33}$

For this analysis we make the empirically plausible assumption that individuals do no discretionary saving or that any such saving is not altered by the transition to a funded program. ${ }^{34}$ Individuals over age 40 when the transition begins remain in the original PAYGO program and are completely unaffected by the transition. Each individual employee who reaches age 40 is given the option of contributing 5 percent of earnings to a personal retirement account for 10 years in addition to the ordinary payroll tax. The funds earn a 9 percent real rate. At the end of the 10 years, when the individual reaches age 50, the individual stops making PRA contributions. Ninety percent of the accumulated PRA balance is then used to fund an annuity over the next 15 years (from ages 50 through 64) with which to reduce the individual's PAYGO taxes. The remaining 10 percent of the fund is retained and used to finance retirement benefits for the individual. The PAYGO benefits that the individual receives are reduced by the amount of these PRA benefits so that his income in retirement is unaffected.

Note first that no one is worse off. Those who choose to participate are clearly better off since they have voluntarily chosen to do so (because the 9 percent return exceeds their personal discount rate as well as the net-of-tax market rate of return that they could otherwise get). Those individuals who are working after the first new cohort of 40 year olds retirees are also better off because their PAYGO taxes can be smaller since the new retirees use the residual 10 percent of

\footnotetext{
${ }^{33} \mathrm{We}$ are grateful to Antonio Rangel for discussions about the feasibility of Pareto improving transitions to funded Social Security.

${ }^{34}$ Recall that median financial assets of households in their immediate preretirement years are equal to only about six months of income. Such small balances are most likely to be regarded as precautionary savings.
} 
their PRA balances to finance retirement annuities that reduce their dependence on PAYGO benefits.

The ability to achieve a Pareto improvement comes in this example from the fact that there is initially a tax on investment income that causes individuals to receive a real rate of return that is less than 9 percent and that the prefunding of Social Security benefits permits circumventing this distortionary tax..$^{35}$ Although it might be objected that the mechanism of this example rests on the assumption that individuals will not offset their PRA saving by other dissaving, we believe that dissaving such large amounts is virtually impossible for most individuals. ${ }^{36}$ The transition implied by this example is extremely slow and more rapid transitions that made no cohort worse off could no doubt be devised. It is not clear however that doing so would be more desirable than a transition with a greater net welfare gain that is not Pareto efficient.

\footnotetext{
${ }^{35}$ Readers who are familiar with the recent papers of Laurence Kotlikoff on privatizing Social Security (e.g., Kotlikoff 1996a, 1996b) will recognize that his examples of Social Security privatizations that produce Pareto improvements get those gains by replacing a distortionary tax (in his case the payroll tax) with a less distorting tax (a consumption tax that raises a substantial amount of revenue during the transition by taxing old capital, i.e., by a lump sum wealth tax).

${ }^{36}$ See footnote 29. Antonio Rangel has suggested a modification of our example that would also lead to a Pareto improvement even if individuals are savers who could in principle offset the mandatory PRA accumulation with reductions in other saving. Rangel's solution to this problem is to replace the 5 percent of payroll PRA contribution with an offer by the government to permit individuals to receive a 9 percent rate of return on saving in excess of what they would otherwise have done. In practice, there would be problems of dealing with previously accumulated assets as well as annual saving flows. Samwick (1996) simulates the effects of several reforms in which households buy themselves out of their existing PAYGO obligations with contributions to PRAs. As in Rangel's example, the reduction in the PAYGO tax is a convex function of the amount contributed. Samwick shows that governments will typically find it optimal to offer different schedules simultaneously to those for whom Social Security contributions are marginal and inframarginal in order to maximize participation while minimizing the reduction in other saving that may occur.
} 


\section{Recognition Bonds and Alternative Transition Financing}

The use of "recognition bonds" is an alternative administrative mechanism to the gradual transition described in this paper. It is part of a broader class of transition mechanisms that combine the gradual transition of the type modeled in section 3 with the use of government debt to shift the burden of the transition to the more distant future.

A "recognition bond" is a government bond given to employees at the time that a PAYGO Social Security program is terminated as compensation for the loss of future benefits or as compensation for the PAYGO taxes that these individuals previously paid. The concept was first suggested by James Buchanan and has actually been used in Chile and Argentina.

Unlike the gradual transition of section 3 , the existing PAYGO system could be ended completely and replaced with an exclusively funded system. Individuals would then be given recognition bonds with which they could in principle purchase (from private financial institutions) a single-premium annuity that would begin its payments at age 65 . The most natural definition of an appropriate recognition bond would be one that is equal to the present actuarial value of the benefits to which the individual is entitled under the PAYGO system. If the value of such a recognition bond is calculated by discounting future benefits at the same rate at which the market is willing to sell a single-premium annuity, the recognition bond would permit the individual to receive the same benefits that he or she would get from the existing PAYGO program.

Three further requirements would make the recognition bond approach exactly identical to the gradual transition of section 3. First, each individual would be required to purchase such an annuity. Second, the individual would be required to make the same contribution to a PRA as provided in section 3 so that the combination of the PRA annuity and the recognition bond annuity 
exactly replaced the original PAYGO benefits. Third, a payroll tax at the same annual rates as used in the section 3 transition would be used to finance the principal and interest payments on the recognition bonds.

These equivalence requirements indicate some alternative transition paths that could be achieved with the help of recognition bonds or, more generally, with the use of explicit government debt as part of the transition. For example, the government could shift some of the burden of the transition from the initial generation of employees to future employees by borrowing some of the funds needed to meet the PAYGO benefits and then amortizing that debt very slowly or not at all. An additional opportunity presented by recognition bonds or by other government debt is to substitute the personal income tax or some other tax for the payroll tax in servicing the explicit debt.

In considering the possible role of explicit government debt it is important to recognize the true cost of using government borrowing. Although government borrowing may appear to have only a low cost because of the low interest rate that the government pays, the crowding out of private investment by government borrowing precludes investments that would be expected to earn the 9 percent real rate of return. We shall not examine the possible uses of debt further at this time.

Table 8 presents estimates of the value of recognition bonds for the United States as owould be payable to individuals at selected ages from 30 through 75 (in thousands of 1995 dollars) as well as the aggregate value of the bonds (in trillions of 1995 dollars). The first four columns are based on a real interest rate of two percent, essentially the real rate of interest paid on government bonds during the past four decades. The second four columns are based on a real interest rate of four percent. 
The recognition bond values in column 1 are the accumulated value of past payroll tax payments. Thus the average 45 year old in 1995 had paid (together with his employers) taxes which, when accumulated with interest at 2 percent, had a cumulated value of $\$ 63,830$. The aggregate value of the claims of all current employees calculated in this way is $\$ 6.703$ trillion. For retirees we cumulate the taxes that they and their employers paid and subtract the benefits that they are deemed to have received after age 64 . The aggregate value of the remaining claims of the retirees is an additional $\$ 1.390$ trillion. The total value of the potential recognition bonds calculated in this way is thus $\$ 8.094$ trillion. Using a 4 percent rate to cumulate past taxes (net of the benefits received by current retirees) produces a total recognition bond debt of $\$ 11.259$ trillion (shown in column 5).

The alternative to this "backward looking" recognition bond is a forward looking recognition bond based on the net future benefits to which the individuals are entitled on the basis of the taxes that they have already paid. Our calculation applies the cohort-specific PAYGO rate of return (see footnote 18 above) to the taxes that the individuals in that cohort would pay to calculate the benefits to which they would be entitled in retirement. The present actuarial value of those benefits is the gross Social Security wealth shown in column 2. The individuals who are 45 years old in 1995 are entitled to benefits under current law that have an actuarial present value of $\$ 120,060$ when discounted at two percent. However, before retiring they would pay additional taxes with an actuarial present value of $\$ 45,860$. Their net Social Security wealth is thus $\$ 74,200$ and that would be the appropriate value of the "forward looking" recognition bond. The cumulative value of such net Social Security "forward looking" recognition bonds, when discounting at 2 percent, is $\$ 11.999$ trillion. That this amount is larger than the aggregate of 
backward looking recognition bonds shows that the current generation of employees and retirees can expect to receive a real return greater than two percent in the existing program. A more detailed comparison by age shows that this is only true above a certain age with those in their early thirties or younger receiving a real return of less than two percent.

Applying a four percent discount rate to calculate forward looking recognition bonds gives a very different result. No working age cohort can expect to receive a real return as high as 4 percent. Individuals who are less than 35 years old have negative net Social Security wealth (the present value of their future taxes exceeds the present value of the benefits when discounted at 4 percent) and would receive no recognition bonds. The aggregate value of the forward looking recognition bonds paid to the remaining workers and retirees would be only $\$ 3.838$ trillion, about half of the backward looking recognition bonds calculated with a 4 percent rate of interest.

Table 8

Backward-Looking and Forward-Looking Recognition Bonds Interest Rate Equals 2 Percent

Interest Rate Equals 4 Percent

\begin{tabular}{|c|c|c|c|c|c|c|c|c|}
\hline & \multirow{3}{*}{$\begin{array}{l}\text { Backward } \\
\text { Looking } \\
\text { Bond }\end{array}$} & \multicolumn{2}{|c|}{ Forward Recognition Bond } & Backward & \multicolumn{3}{|c|}{ Forward Recognition Bond } & \multirow{3}{*}{ Net } \\
\hline & & Gross & SS Tax Net & & & Gross & SS Tax & \\
\hline & & SSW & SSW & Bond & SSW & & SSW & \\
\hline e & & & & & & & & \\
\hline 30 & 19,950 & $98,580 \quad 79,190$ & 19,390 & 21,540 & 41,080 & 59,570 & $-18,490$ & \\
\hline 45 & 63,830 & $120,060 \quad 45,860$ & 74,200 & 78,920 & 67,890 & 39,090 & 28,800 & \\
\hline 60 & 94,980 & $157,87010,980$ & 146,890 & 133,540 & 119,660 & 10,580 & 109,080 & \\
\hline 75 & 3,270 & 72,460 & 72,460 & 48,830 & 63,770 & $\mathbf{0}$ & 63,770 & \\
\hline
\end{tabular}

Totals in Trillions of 1995 Dollars

$\begin{array}{lllllllll}\text { Workers } & 6.703 & 16.317 & 7.949 & 8.369 & 8.474 & 8.905 & 6.227 & 3.838^{*} \\ \text { Retirees } & 1.390 & 3.631 & 0 & 3.630 & 2.785 & 3.153 & 0.000 & 3.153 \\ \text { TOTAL } & 8.094 & 19.948 & 7.949 & 11.999 & 11.259 & 12.058 & 6.227 & 6.991^{*}\end{array}$

*Excludes individuals with negative net Social Security wealth. 


\section{Social Security Prefunding and Low Wage Workers}

The prefunded system of benefits based on individual accounts that is described in section 2 involves no redistributions and makes retirement annuities proportional to preretirement earnings. It is possible, however, to introduce a variety of modifications that can make prefunding even more advantageous to low wage workers than to those with average and above average wages.

In a previous paper (Feldstein and Samwick, 1996) we used data on the distribution of lifetime earnings to calculate the distribution of PRA fund values at age 65 . We found that 19 percent of accounts had less than half of the value of the median account. The cost of supplementing all such "low value" accounts by enough to bring them up to half of the median value could be financed by a one-time tax of 4.7 percent on all PRA accounts at age 65 . Each individual could save enough to provide for his own PRA annuity and to finance that one-time tax by raising his PRA contribution rate by 4.7 percent; in the current calculation, the long-run PRA contribution would have to rise from of 2.02 percent of payroll to 2.11 percent of payroll.

In the present paper we pursue a very different approach and ask how a low income worker might fare in a funded system and what would have to be done to provide the same level of retirement benefits that such workers receive in the existing PAYGO system. For this purpose, we follow the Social Security Administration and define the low wage worker as someone with 45 percent of average covered earnings, i.e., with earnings of only $\$ 11,617$ in 1996 . Under current law, such individuals receive benefits equal to 55 percent of their immediate preretirement income if they have no dependents and 83 percent of that preretirement income with a dependent spouse.

Consider first the fraction of earnings that such a low wage worker would have to 
contribute to a PRA account from ages 30 to 65 to finance an annuity equal to 83 percent of preretirement earnings from age 65 to death. To provide an explicit and transparent calculation, we avoid the complexity of an actuarial annuity and assume instead that the individual receives a fixed annuity for 20 years starting at age 65 . If the low income individual's wage grows at 1 percent a year from age 30 to age 64 and the PRA account earns a real return of 9 percent, the value of the PRA account at age 65 is $\mathrm{c} \mathrm{w} \Sigma_{1}{ }^{35}(1.01)^{\mathrm{t}}(1.09)^{35-t}$ where $\mathrm{c}$ is the proportion of the wage that is saved in the PRA each year and $w$ is the wage at age 30 . If the annuity is to be 83 percent of the immediate preretirement wage, i.e., $0.83 \mathrm{w}(1.01)^{35}$,for twenty years, the value of $\mathrm{c}$ must satisfy $\mathrm{c}$ $\Sigma_{1}{ }^{35}(1.01)^{\mathrm{t}}(1.09)^{35-t}=0.83(1.01)^{35} \Sigma_{1}{ }^{20}(1.09)^{-t}$. This implies $\mathrm{c}=0.045$. Thus even with no redistribution, the low wage earner could obtain the 83 percent replacement rate of the current PAYGO system with a PRA contribution of only 4.5 percent of wages instead of the 18.75 percent long-term contribution implied by current law and PAYGO financing. The low wage earner would thus have an increase in disposable income equal to more than 14 percent of earnings.

The idea that the low wage workers would be required to make higher proportional contributions to their PRAs than higher wage workers might be politically unacceptable even though such contributions would be very much less than they would have been in the PAYGO system. We therefore ask how their rate of return would have to be augmented by an explicit transfer to produce the 83 per cent replacement rate if the low wage worker made the same PRA contribution as a percent of payroll as everyone else. This incremental return might come from the additional corporate income tax revenue that the government collects as a result of the PRA capital by giving more of that extra tax to lower income individuals and less to those with higher incomes.

If the low wage earner contributes 2 percent of earnings to a PRA and obtains a return of $R$ 
percent on his PRA balances, at the time of retirement the balance in the account would be $0.02 \mathrm{w}$ $\Sigma_{1}{ }^{35}(1.01)^{\mathrm{t}}(1+\mathrm{R})^{35-t}$. If benefits are to be $0.83(1.01)^{35} \mathrm{w}$ for 20 years, R must satisfy $0.02 \mathrm{w} \Sigma_{1}{ }^{35}$ $(1.01)^{\mathrm{t}}(1+\mathrm{R})^{35-\mathrm{t}}=0.83(1.01)^{35} \mathrm{~W} \Sigma_{1}{ }^{20}(1+\mathrm{R})^{-\mathrm{t}}$. This implies that the required rate of return for the low wage earner would be $R=0.118$. In short, if the government used part of the incremental corporate income tax revenue (equal to about 3.5 percent of all PRA assets) to increase the rate of return on the assets of the low wage earners by 2.8 percentage points, the low income earner could obtain the same 83 percent replacement rate as under existing law with a contribution of only 2 percent of earnings.

There are undoubtedly other and better ways to achieve any desired redistribution to supplement the benefits of low wage earners. Although we will not explore this issue further here, we believe that the calculations in this section show that a prefunded system can provide the same level of retirement income to low wage earners as the current PAYGO system with at least 14 per cent higher income during preretirement years or some combination of higher income during both retirement and preretirement years.

\section{7. $\quad$ Asset Market Risk}

Many people object to the idea of a funded system of individual retirement accounts because of the risks associated with the asset market uncertainty. ${ }^{37}$ In our earlier paper (Feldstein and Samwick, 1996), we argued that a small increase in the amount saved could reduce to a very

\footnotetext{
${ }^{37}$ It is of course wrong to regard the current PAYGO benefits as providing a riskless return on past payroll taxes. The benefits that future retirees will receive in exchange for their current PAYGO taxes depends on the future rates of growth of wage rates and of the labor force and on the even more uncertain political decisions about the level of the Social Security payroll tax. For a discussion of the riskiness of the PAYGO system, see Feldstein (1996a) and the introductory chapter in Feldstein (1996b).
} 
low level the risk of receiving less from the funded program than the benefits promised in the existing PAYGO system. The current analysis differs from our previous paper in two important ways. First, we have modified the stochastic process describing the fluctuations in asset prices to examine a broader range of possible asset market outcomes. Second, we now separate the market risk from the longevity risk, i.e., the risk that an individual will live in retirement for an unusually long time. In the previous paper, we made the unnecessary and extreme assumption that annuities do not exist, requiring individuals to protect themselves by increased saving against longevity risk as well as market risk. A more realistic assumption is that variable annuities (that invest in equities as well as debt) do exist and that replacing the current PAYGO Social Security system with a universal funded retirement program would help to perfect the market for such variable rate annuities. We therefore assume that all PRA saving is used to purchase annuities that are invested in the market portfolio of stocks and bonds that have an implicit expected return of 9 percent. The annuities are of course subject to a market value risk due to fluctuations in debt and equity prices.

For the current analysis, we do not deal with the transition to a funded system but focus just on the long run in which the PRA system has completely replaced the PAYGO system. In this framework, we calculate the extent to which raising the PRA saving rate reduces the risk that the PRA account will not be able to provide the level of benefits that would have been provided by the PAYGO program.

In section 2 of this paper, where we assumed a 9 percent rate of return with no uncertainty, we found that the PAYGO benefits could be financed by PRA contributions of 2.02 percent of payroll between ages 30 and 64 . We now find that, with realistic stochastic variation in stock and bond prices, PRA contributions of less than three percent of payroll are sufficient to provide those 
benefits with virtual certainty, i.e., with a probability greater than 0.99 . Even with very extreme fluctuations in return, the needed PRA saving would be less than five percent of payroll. In all of these instances, the cohort will leave a positive bequest to the next generation (either to individuals or to the government).

To explain the basis of this conclusion, we now describe the impact of market price fluctuations on the PRA annuities and then discuss how additional saving can provide the desired risk protection. Note that each age cohort provides its own protection in this way. Although explicit market trades among different age cohorts could no doubt achieve the same protection at lower cost in terms of incremental saving, we do not explore that possibility here.

To describe the evolution of the PRA accounts, we use the following notation: $M(t)$ is the market value of the cohort's PRA accounts in year $t ; Q(t)$ is the ratio of the market value of a market mixture of debt and equity to the real value of the underlying capital stock; $S(t)$ is the cohort's PRA contribution in year $t$; and $K(t)$ is the real value of the assets in the PRA account, i.e., $M(t)=Q(t) \times K(t)$.

We focus on the fluctuations in the market value of stocks and bonds and ignore the variations in the real return on physical capital. Thus the physical capital stock yields a sure real return of 9 percent. The government takes 3.5 percent of this in corporate taxes which it returns to the PRA annuities. Real dividends and interest are 3.0 percent, leaving retained earnings of 2.5 percent of capital. This grows during the preretirement years because of the retained earnings and because of the investment of dividends, interest, corporate tax rebates and new PRA 
contributions. ${ }^{38}$ Although the retained earnings add dollar for dollar to the real capital stock, the amount of real capital purchased by the other external investments depends on the level of $Q(t)$. Thus the real capital stock in the PRA evolves during the preretirement years according to:

$$
\mathrm{K}(\mathrm{t}+1)=1.025 \mathrm{~K}(\mathrm{t})+0.065 \mathrm{~K}(\mathrm{t}) / \mathrm{Q}(\mathrm{t})+\mathrm{S}(\mathrm{t}+1) / \mathrm{Q}(\mathrm{t}+1)
$$

and the corresponding market value of the capital stock is

$$
\mathrm{M}(\mathrm{t}+1)=\mathrm{Q}(\mathrm{t}+1)[1.025 \mathrm{~K}(\mathrm{t})]+0.065 \mathrm{Q}(\mathrm{t}+1) \mathrm{K}(\mathrm{t}) / \mathrm{Q}(\mathrm{t})+\mathrm{S}(\mathrm{t}+1)
$$

After retirement, the annual contributions cease and the market value of the capital stock is reduced by withdrawing the baseline benefits $[\mathrm{B}(\mathrm{t})]$ according to

$$
\mathrm{M}(\mathrm{t}+1)=\mathrm{Q}(\mathrm{t}+1)[1.025 \mathrm{~K}(\mathrm{t})]+0.065 \mathrm{Q}(\mathrm{t}+1) \mathrm{K}(\mathrm{t}) / \mathrm{Q}(\mathrm{t})-\mathrm{B}(\mathrm{t}+1)
$$

where the physical capital stock evolves according to an equation like equation 7.1 with the $S(t+1)$ value replaced by $-\mathrm{B}(\mathrm{t}+1)$. We assume the benefits are set to equal the benefits provided by the PAYGO Social Security rules for each surviving retiree.

This is a stochastic relationship because $\mathrm{Q}(\mathrm{t})$ varies randomly from year to year. We model the evolution of $\mathrm{Q}(\mathrm{t})$ as a random walk. ${ }^{39}$

$$
\text { (7.4) } \ln Q(t+1) \quad=\ln Q(t)-0.5 \sigma_{v}^{2}+u_{t}
$$

where $u_{t}$ is normally distributed with variance $s_{u}^{2} \cdot{ }^{40}$

${ }^{38}$ When an individual dies, that individual's PRA assets are assumed to remain in the cohort's annuity accounts. When the cohort reaches age 100 , the last individual is assumed to die and the remaining assets revert to the government.

${ }^{39}$ Equation 7.4 replaces the econometrically estimated autoregressive equation (presented as equation 4 in our previous paper.).

${ }^{40}$ Since $Q(t)$ is lognormally distributed, the term $-0.5 \sigma^{2}$ makes the expected value of $\mathrm{Q}(\mathrm{t}+1) / \mathrm{Q}(\mathrm{t})$ equal to one. The term 0.065 in equation 1 is also adjusted for the variation in $\mathrm{Q}(\mathrm{t})$ so that the expected rate of return in 1000 simulations remains 9 percent. 
We analyze this model with three different values of $\mathrm{s}_{\mathrm{u} .}$ For the years 1947 through 1995, the historic average value of $s_{u}$ for equity prices was 0.186 , we use $s_{u}=0.186$ even though this exceeds the historic experience with a diversified stock-bonds portfolio. We also analyze two much larger values $\left(s_{u}=0.50\right.$ and $\left.s_{u}=0.75\right)$ that imply much greater variability of $Q(t)$.

In the historic sample from 1947 through 1995, the minimum value of $Q(t)$ was 0.319 and the maximum value was $1.467 .^{41}$ To see the variability of $Q(t)$ implied by $s_{u}=0.50$ and $s_{u}=0.75$, we performed 1000 simulations of a 70 year path of $Q(t)$ values for each value of $s_{u}$. With $s_{u}=$ 0.50 , the value of $Q(t)$ was below 0.47 in 10 percent of the 70,000 simulation years and below 0.39 in five percent of those simulation years. The value of $\mathrm{Q}(\mathrm{t})$ was also above 1.68 in 10 percent of realizations and above 2.02 in 5 percent of realizations. Thus $s_{u}=0.50$ corresponds to much greater variability of $Q(t)$ than has been observed in the postwar period in the United States. With $s_{u}=0.75$, the variation in $Q(t)$ is even greater. Ten percent of $Q(t)$ values are below 0.22 and ten percent are above 1.99 .

Combining equations (7.1) through (7.4), we simulate the time path of $\mathrm{M}(\mathrm{t})$ for the representative cohort in long-run equilibrium on the assumption that its members start contributing to a PRA at age 30, work until age 64 and then dissave the level of benefits provided by existing Social Security rules. The number of surviving members of the age cohort shrinks each year because of nonstochastic age specific mortality rates. As the size of the cohort shrinks, the average aggregate amount of benefits also declines.

We repeat the simulations for four different assumptions about the PRA contribution rate.

\footnotetext{
${ }^{41}$ See Poterba and Samwick (1995). Note that these Q(t)values are for the market mixture of debt and equity.
} 
The first corresponds to assuming the expected 9 percent real rate of return. These savings are just sufficient to fund the benefits when there is no market risk. With variations in asset returns, the PRA accounts will be exhausted before the last annuitant dies in a large fraction of cases. This is avoided however by increasing the PRA contribution rate to the rate that would be needed in the nonstochastic case with a lower expected return. The other simulations (summarized in Table 9 ) correspond to the saving that would be necessary with no uncertainty but lower rates of return: 8 percent, 7 percent and 6 percent. With the 8 percent rate of return, the PRA contribution rate is increased from 2.02 percent of covered earnings to 2.70 percent. With the 7 percent and 6 percent returns, the PRA contribution rates are 3.61 percent and 4.81 percent of covered earnings.

For each saving rate, we repeat the simulation 1000 times and note the fraction of times that the cohort still has positive PRA assets when its surviving members reach age 100 . The results are summarized in Table 9.

Table 9

Effects of Alternative Stochastic Assumptions on the Variation of $Q(t)$ and the Probability of Asset Exhaustion

\begin{tabular}{|c|c|c|c|c|c|c|c|c|}
\hline \multirow{5}{*}{$\begin{array}{c}\text { Standard Deviation } \\
\text { Of Disturbance } \\
\qquad \sigma_{v}\end{array}$} & \multicolumn{4}{|c|}{ Distribution of Q(t) Values } & \multirow{2}{*}{\multicolumn{4}{|c|}{$\begin{array}{l}\text { Probability of Paying Annuity to Age } 100 \\
\text { PRA Contributions as if Return is: }\end{array}$}} \\
\hline & \multirow{4}{*}{$5^{\text {th }}$} & \multirow{4}{*}{$10^{\text {th }}$} & \multirow{4}{*}{$90^{\text {th }}$} & \multirow{4}{*}{$95^{\text {th }}$} & & & & \\
\hline & & & & & $9.0 \%$ & $8.0 \%$ & $7.0 \%$ & $6.0 \%$ \\
\hline & & & & & \multicolumn{4}{|c|}{ PRA share of covered earnings: } \\
\hline & & & & & 2.02 & 2.70 & 3.61 & 4.81 \\
\hline 0.186 & 0.72 & 0.77 & 1.25 & 1.34 & 0.474 & 1.000 & 1.000 & 1.000 \\
\hline 0.500 & 0.39 & 0.47 & 1.68 & 2.02 & 0.440 & 0.874 & 0.999 & 1.000 \\
\hline 0.750 & 0.22 & 0.29 & 1.99 & 2.62 & 0.423 & 0.724 & 0.927 & 0.992 \\
\hline
\end{tabular}

With the historic experience $\left(\sigma_{v}=0.186\right)$, a PRA contribution rate of 2.70 percent of 
covered earnings (corresponding to the saving that would be done with a sure 8 percent return) implies that the cohort is virtually certain to continue making annuity payments until the cohort reaches age 100 . In 1000 simulations, there was none with insufficient assets.

With much more market risk (corresponding to $\sigma_{v}=0.50$ ) a PRA contribution rate of 2.70 percent is not adequate in 12.6 percent of the simulations. But increasing the contribution to 3.61 percent achieves virtual certainty with sufficient assets in 999 of the 1000 simulations. Even with the implausibly large uncertainty corresponding to $\sigma_{v}=0.75$ (implying that ten percent of the $\mathrm{Q}(\mathrm{t})$ values are below 0.22 or above 2.62), annuitants are virtually certain to receive benefits to age 100 if the PRA contribution rate is 4.81 percent of payroll. Note that even in this least favorable case the PRA contribution is only about one-fourth of the 18.75 percent payroll tax that would be required in a PAYGO system.

In those rare cases in which the market fluctuations prevent the annuities from paying the intended benefits, the government might have to act as insurer of last resort. It is interesting to ask therefore how large the implied contingent liability would be. Consider for example the case in which $\sigma_{v}=0.75$ and the PRA contribution rate is set too low at 3.61 percent of covered earnings. In this case, there is a 7.3 percent probability that the government would have to make annuity payments after the PRA accounts are exhausted. But even here we find that the present actuarial value discounted at 4 percent (as of the year when the cohort becomes 65 years old,) of the government's conditional payment per retiree is only $\$ 26,600$, less than three years income. The expected value of this payment, taking into account the 7.3 percent probability of payment, is only $\$ 1942$ per retiree.

This "oversaving" approach to eliminating risk is undoubtedly a very inefficient way for 
each age cohort to protect its members. It permits no adjustment of benefits to the realized returns and no risk-sharing with older and younger cohorts. It involves leaving a large unintended bequest. But it is sufficient to show that even a very inefficient way of dealing with portfolio risk still permits achieving a virtual certainty of retirement benefits as great as those in the PAYGO system with a very much lower annual contribution during working years.

\section{8. $\quad$ Medicare}

Although we have focused our detailed analysis on the prefunding of Social Security benefits, we believe that the same logic can be applied to financing the health care benefits of the aged. As we noted in section 1, the cost of funding health care for the aged on a PAYGO basis would eventually require a payroll tax equal to about 12 percent of GDP or about 30 percent of covered earnings.

Since the long-run projected cost of the health care programs for the aged is about 170 percent of the long-run level of aggregate Social Security benefits, a first approximation of the payroll contributions needed to fund these health benefits is 170 percent of the PRA contributions that are required to fund the Social Security retirement benefits. This implies contributions to a "Personal Retirement Health Account" (PRHA) of 3.4 percent of taxable payroll, only slightly higher than the current Medicare payroll tax of 2.9 percent. The funds accumulated in this way could be used to purchase conventional insurance like the existing Medicare coverage plus the long-term care insurance currently provided by Medicaid. Alternatively, the funds could pay for membership in a health maintenance organization or could be used in conjunction with high deductible health insurance policies as a way of achieving greater 
self-control over health expenditures. Although the precise way in which the accumulated funds are translated into the financing of health care is very important, it is secondary to the financing issue that we consider here.

One further point that does need discussion here is that the health benefits provided by Medicare, unlike the cash retirement benefits, are not related to earnings during working years. The 3.4 percent of payroll contribution to a PRHA would therefore provide a larger than needed fund for those with above average earnings but an inadequate fund for those with below average income. One possible solution to this problem is to redistribute the contribution so that each individual pays 3.4 percent of his earnings up to the maximum taxable earnings for Social Security ( $\$ 65,400$ at 1997 levels) but only keeps (or receives) enough to contribute the same average amount to a PRHA (i.e., an amount equal to 3.4 percent of average covered earnings, about $\$ 25,900$ at the 1997 level).

\section{Concluding Remarks}

Designing an appropriate way to finance the retirement and health care benefits of the aging population is probably the most important challenge to government finance in the decades ahead. If it is done wisely, the aged will have comfortable retirements and the advantages of improving medical technology while the working population will avoid the explosive growth of taxes that could otherwise occur. 


\section{References}

Auerbach, Alan, Jagdeesh Gokhale and Laurence Kotlikoff "Generational Accounts: A Meaningful Alternative to Deficit Accounting," in D. Bradford. Tax Policy and the Economy 1991

Auten, Gerald and R. Carroll. "Taxpayer Behavior and the 1986 Tax Reform Act," Treasury Department Office of Tax Analysis, July 1994.

Boskin, Michael, Laurence Kotlikoff, Douglas Puffert and John Shoven. "Social Security: A Financial Appraisal Across and Within Generations," National Tax Journal, 40, 1987, pp 19-34.

Committee on Ways and Means. The 1996 Green Book. Washington D.C.: Government Printing Office. 1996

Congressional Budget Office. The Economic and Budget Outlook: Fiscal Years 1997-2006. Washington, D.C.: Government Printing Office. 1996

Feldstein, Martin. "The Welfare Cost of Capital Income Taxation," Journal of Political Economy, Vol. 86, No. 2, Part 2, 1978.

Feldstein, Martin. "The Effect of Marginal Tax Rates on Taxable Income: A Panel Study of the 1986 Tax Reform Act," Journal of Political Economy, (103:3), June 1995a, pp 551-72.

Feldstein, Martin. "Tax Avoidance and the Deadweight Loss of the Income Tax," NBER Working Paper No. 5055, March 1995b. Review of Economics and Statistics, forthcoming.

Feldstein, Martin. "The Missing Piece in Policy Analysis: Social Security Reform," The Richard T. Ely Lecture, in American Economic Review, Vol. 86, No. 2, May 1996a, pp 1-14.

Feldstein, Martin Privatizing Social Security, Chicago: University of Chicago Press, forthcoming (1996b)

Feldstein, Martin. "How Big Should Government Be?" National Tax Journal, 1997 (forthcoming)

Feldstein, Martin and Andrew Samwick "The Transition Path in Privatizing Social Security," NBER Working Paper 5761, 1996, förthcoming in M. Feldstein Privatizing Social Security, Chicago: University of Chicago Press, forthcoming

Kotlikoff, Laurence. "Privatization of Social Security: How It Works and Why It Matters," in James Poterba (ed.), Tax Policy and the Economy, 1996a 
Kotlikoff, Laurence. Simulating the Privatization of Social Security in General Equilibrium," forthcoming in Martin Feldstein, Privatizing Social Security, 1996b

Poterba, James and Andrew Samwick. "Stock Ownership Patterns, Stock Market Fluctuations, and Consumption," Brookings Papers on Economic Activity, 2:1995, pp 295-357.

Rippe, Richard. "Further Gains in Corporate Profitability," Economic Outlook Monthly, Prudential Securities, Inc., August 1995.

Samuelson, Paul. "An Exact Consumption Loan Model of Interest With or Without the Social Contrivance of Money," Journal of Political Economy, 1958.

Samwick, Andrew "Discount Rate Heterogeneity and Social Security Reform," Manuscript, Dartmouth College, November 1996 